\title{
Paenalcaligenes hominis gen. nov., sp. nov., a new member of the family A/caligenaceae
}

\author{
P. Kämpfer, ${ }^{1}$ E. Falsen, ${ }^{2}$ S. Langer, ${ }^{3}$ N. Lodders ${ }^{1}$ and H.-J. Busse ${ }^{3}$ \\ ${ }^{1}$ Institut für Angewandte Mikrobiologie, Justus Liebig Universität, D-35392 Giessen, Germany \\ ${ }^{2}$ Culture Collection University Göteborg, Department of Clinical Bacteriology, S-41346 Göteborg, \\ Sweden \\ ${ }^{3}$ Institut für Bakteriologie, Mykologie und Hygiene, Veterinärmedizinische Universität Wien, \\ Veterinärplatz 1, A-1210 Wien, Austria
}

\begin{abstract}
Correspondence
Peter Kämpfer

peter.kaempfer@umwelt.unigiessen.de
\end{abstract}

\begin{abstract}
A beige-pigmented bacterium (strain CCUG $53761 \mathrm{~A}^{\top}$ ) was isolated from human blood from an 85-year-old man in Göteborg, Sweden. Comparative analysis of 16S rRNA gene sequences showed that this bacterium displayed $<95 \%$ similarity to all described species of the genera of the family Alcaligenaceae. It grouped within the radiation of the genus Alcaligenes, but showed only 93.0-94.8\% similarity to type strains of members of this genus (Alcaligenes faecalis subsp. parafaecalis, 94.8\%; Alcaligenes faecalis subsp. faecalis, 94.2\%; Alcaligenes faecalis subsp. phenolicus, $93.4 \%$ ). This discrimination was supported by chemotaxonomic differences. The polyamine pattern consisted of the predominant compound putrescine, moderate amounts of spermidine and minor to trace amounts of spermine and cadaverine; 2-hydroxyputrescine was not detectable. The quinone system was ubiquinone Q-8 with minor amounts of Q-7. The polar lipid profile was composed of the major lipids diphosphatidylglycerol and phosphatidylethanolamine and moderate amounts of phosphatidylglycerol and an unknown phospholipid; minor lipids were also detected. The fatty acid profile, with large amounts of $C_{16: 0}$ and $C_{17: 0}$ cyclo and the absence of $\mathrm{C}_{12: 0} 2-\mathrm{OH}$ as hydroxylated fatty acid, also differed significantly from those reported for A/caligenes species. On the basis of these data, it is proposed that strain CCUG $53761 \mathrm{~A}^{\top}$ represents a novel genus and species, for which the name Paenalcaligenes hominis gen. nov.,

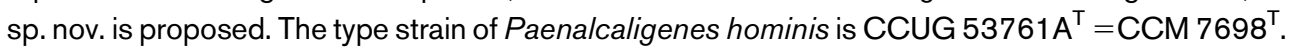

The family Alcaligenaceae was proposed by De Ley et al. (1986) to accommodate the genera Bordetella and Alcaligenes. Subsequently, the genera Achromobacter, Advenella, Castellaniella, Pigmentiphaga, Pusillimonas and Kerstersia have been assigned to the family (Yabuuchi et al., 1998; Blümel et al., 2001; Coenye et al., 2003a, 2005; Kämpfer et al., 2006; Stolz et al., 2005). The genera Oligella, Taylorella, Pelistega, Brackiella and Tetrathiobacter are closely related to the Alcaligenaceae but have not been formally assigned to this family (Rossau et al., 1987; Vandamme et al., 1998; Willems et al., 2002; Ghosh et al., 2005). Members of most of these genera have been isolated from various human, animal and environmental samples, but some of them (e.g. Pigmentiphaga kullae, Tetrathiobacter species) appear to be truly environmental organisms, which have not been associated with human or animal diseases. Members of the family stain Gram-negative and are either strictly aerobic or facultatively anaerobic rods or coccobacilli that are motile.

Abbreviations: pNA, $p$-nitroanilide; pNP, $p$-nitrophenyl.

The GenBank/EMBL/DDBJ accession number for the 16S rRNA gene sequence of strain CCUG $53761 \mathrm{~A}^{\top}$ is FN391024.
They possess oxidase and catalase. All grow well on complex media such as nutrient agar.

Strain CCUG $53761 \mathrm{~A}^{\mathrm{T}}$ was isolated on blood agar at $37{ }^{\circ} \mathrm{C}$ from human blood of an 85-year-old man in Göteborg, Sweden. Subcultivation was done on nutrient agar (NA; Oxoid) at $30{ }^{\circ} \mathrm{C}$ for $24 \mathrm{~h}$. Gram staining was performed with the standard procedure as described by Gerhardt et al. (1994). Cell morphology was examined with a Zeiss light microscope at $\times 1000$ magnification, using cells that had been grown for $24 \mathrm{~h}$ at $30{ }^{\circ} \mathrm{C}$ on NA.

The 16S rRNA gene was analysed as described by Kämpfer et al. (2003). DNA extraction was carried out using the GenElute Plant Genomic DNA kit (Sigma-Aldrich) according to the manufacturer's instructions. The $16 \mathrm{~S}$ rRNA gene was amplified by PCR using the primer pair 27F (5'-GAGTTTGATCMTGGCTCAG) and MR 1492R (5'-ACGGYTACCTTGTTACGACTT) (Lane, 1991) and the following cycling conditions: $95{ }^{\circ} \mathrm{C}$ for $3 \mathrm{~min}, 28$ cycles of $94{ }^{\circ} \mathrm{C}$ for $1 \mathrm{~min}, 57.3{ }^{\circ} \mathrm{C}$ for $45 \mathrm{~s}$ and $72{ }^{\circ} \mathrm{C}$ for $2 \mathrm{~min}$ and a final elongation step at $72{ }^{\circ} \mathrm{C}$ for $15 \mathrm{~min}$. The PCR product was purified with the QIAquick PCR 
purification kit (Qiagen) according to the manufacturer's instructions. The PCR product was then sent to a sequencing service (Institute of Microbiology and Molecular Biology, Justus-Liebig-University Giessen, Giessen, Germany) and sequenced with standard sequencing primers for the $16 \mathrm{~S}$ rRNA gene. Phylogenetic analysis was performed using the ARB software package (December 2007 version; Ludwig et al., 2004) and the corresponding SILVA SSURef 95 database (July 2008 version; Pruesse et al., 2007). Trees were reconstructed using the maximum-likelihood method with fastDNAml (Olsen et al., 1994) and 50\% conservation filter (only alignment columns in which the frequency of the most abundant nucleotide is equal to or greater than $50 \%$ are included in the calculation). Tree topology was further tested without filters. No significant differences could be detected between these trees regarding the grouping of strain CCUG $53761 \mathrm{~A}^{\mathrm{T}}$. Trees reconstructed with neighbour-joining and maximum-parsimony methods showed similar results (not shown). The almost-complete 16S rRNA gene sequence (1398 bp) of the strain was compared by distance calculations (distance options according to the Kimura-2 model) using the software package MEGA version 4.0 (Tamura et al., 2007). The results of these calculations indicated that the closest relatives of strain CCUG $53761 \mathrm{~A}^{\mathrm{T}}$ were Alcaligenes faecalis subsp. parafaecalis $\mathrm{G}^{\mathrm{T}}(94.8 \%$ similarity), Alcaligenes faecalis subsp. faecalis IAM $12369^{\mathrm{T}}$
(94.2\%) and Pusillimonas noertemannii $\mathrm{BN9}^{\mathrm{T}}$ (94.3\%). Lower sequence similarities $(<94.2 \%)$ were found with members of all other genera of the family Alcaligenaceae and with Alcaligenes faecalis subsp. phenolicus $\mathrm{J}^{\mathrm{T}}(93.4 \%)$. A maximum-likelihood tree is shown in Fig. 1; the close relationship to the genus Alcaligenes is obvious.

For extraction of quinones, polar lipids and polyamines, biomass was grown on PYE medium $(0.3 \%$ yeast extract, $0.3 \%$ peptone from casein, $\mathrm{pH} 7.2$ ). Extraction of respiratory quinones and polar lipids was carried out according to the procedure described by Tindall $(1990 \mathrm{a}, \mathrm{b})$ and Altenburger et al. (1996). Polyamines were extracted from cells harvested at the late exponential growth phase as reported by Busse \& Auling (1988). HPLC analysis of quinones and polyamines was carried out using the apparatus described by Stolz et al. (2007). Fatty acids were extracted and analysed according to Kämpfer \& Kroppenstedt (1996). The polyamine pattern was composed of putrescine $\left[104.1 \mu \mathrm{mol}(\mathrm{g} \text { dry weight })^{-1}\right]$, spermidine $\left.[3.2 \mu \mathrm{mol} \text { (g dry weight })^{-1}\right]$, spermine $[1.1 \mu \mathrm{mol}$ (g dry weight $\left.)^{-1}\right]$ and cadaverine $\left[0.3 \mu \mathrm{mol}(\mathrm{g} \text { dry weight })^{-1}\right]$, but 2-hydroxyputrescine was not detectable. A polyamine pattern with the predominant compound putrescine and moderate to minor concentrations of spermidine is common for species of the Betaproteobacteria (Busse \& Auling, 1988;

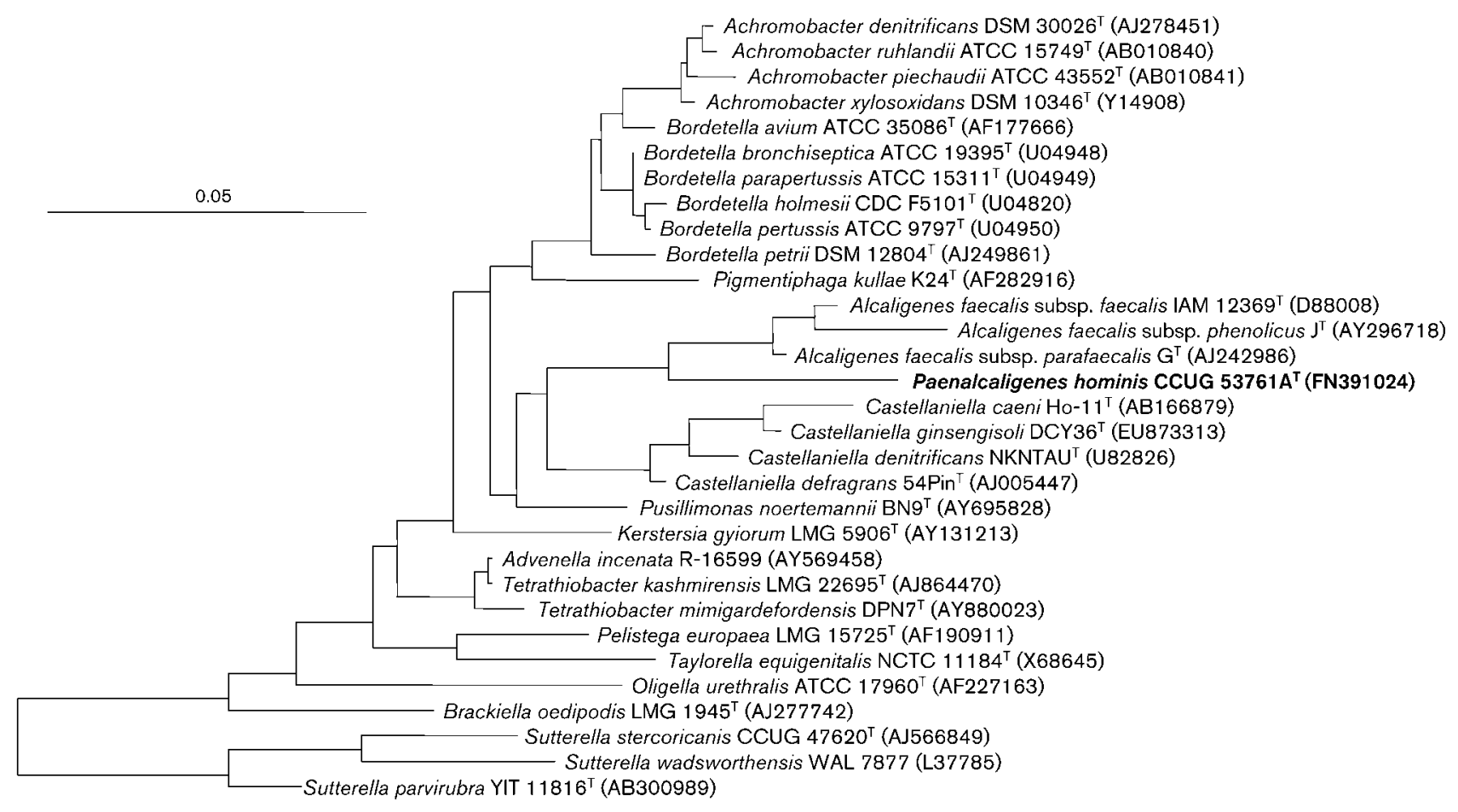

Fig. 1. Phylogenetic analysis based on $16 \mathrm{~S}$ rRNA gene sequences available from the EMBL database (accession numbers in parentheses). The phylogenetic tree was constructed using the ARB software package (December 2007 version; Ludwig et al., 2004) and the corresponding SILVA SSURef 95 database (July 2008 version; Pruesse et al., 2007). Tree building was performed using the maximum-likelihood method with fastDNAml (Olsen et al., 1994) and no conservation filter. Bar, 0.05 substitutions per nucleotide position. 
Auling et al., 1991; Busse et al., 1992; Hamana \& Takeuchi, 1998; Hamana et al., 2000, 2007). Lack of detectable amounts of 2-hydroxyputrescine is uncommon among species of the family Alcaligenaceae. All species of the family analysed for polyamines have been shown to contain significant amounts of 2-hydroxyputrescine (Busse \& Auling, 1988; Hamana \& Takeuchi, 1998; Stolz et al., 2005; Kämpfer et al., 2006), but Alcaligenes faecalis subsp. parafaecalis was reported to contain only trace amounts of this diamine. Hence, this polyamine pattern clearly distinguishes CCUG $53761 \mathrm{~A}^{\mathrm{T}}$ from all recognized species of the family Alcaligenaceae, but further analyses of polyamines are needed to substantiate the uniqueness of this trait, since not all species of the family have been examined so far. Examination of close relatives of CCUG $53761 \mathrm{~A}^{\mathrm{T}}$ is also desirable in order to collect knowledge about the stability of this trait within the proposed taxon. However, outside the family Alcaligenaceae, certain species of the class Betaproteobacteria have been reported to lack 2-hydroxyputrescine, such as Kingella denitrificans, Kingella kingae, Kingella oralis, Oxalobacter formigenes, Vitreoscilla beggiatoides and Vitreoscilla stercoraria (Hamana et al., 2000), but these taxa are quite distantly related to the family Alcaligenaceae, being placed on separate lines within the Betaproteobacteria (Moreira et al., 2000; Kirchhof et al., 2001). The quinone system consisted of ubiquinone Q-8 (93\%) and Q-7 (7\%), which is consistent with classification in the Betaproteobacteria (Yokota et al., 1992). The polar lipid profile was composed of the major compounds phosphatidylethanolamine and diphosphatidylglycerol, moderate amounts of phosphatidylglycerol and an unidentified phospholipid and minor amounts of three unidentified lipids and two unidentified aminolipids, one of which (AL2) corresponded to AL4 reported to be present in Castellaniella defragrans and Alcaligenes faecalis. This profile was less complex than those reported for species of the closely related genera Alcaligenes, Castellaniella and Pusillimonas (Stolz et al., 2005; Kämpfer et al., 2006) and contained characteristics useful for differentiation from these taxa (Fig. 2). The presence of the unidentified phospholipid PL (Fig. 2) and the lack of unidentified aminolipid AL1 present in Alcaligenes faecalis, Castellaniella defragrans, Castellaniella denitrificans and Pusillimonas noertemannii (Stolz et al., 2005; Kämpfer et al., 2006) distinguish CCUG 53761A ${ }^{\mathrm{T}}$ from these related species. Lack of unidentified aminolipid AL2 allows specific differentiation of CCUG $53761 \mathrm{~A}^{\mathrm{T}}$ from Pusillimonas noertemannii.

The fatty acid profile of strain CCUG $53761 \mathrm{~A}^{\mathrm{T}}$ is given in Table 1 . The fatty acid profile is dominated by $\mathrm{C}_{16: 0}, \mathrm{C}_{17: 0}$ cyclo and summed feature $3\left(\mathrm{C}_{16: 1} \omega 7 c\right.$ and/or $\mathrm{C}_{15: 0}$ iso 2$\mathrm{OH})$. The hydroxylated fatty acid $\mathrm{C}_{12: 0} 2-\mathrm{OH}$, present in all Alcaligenes species, was not found.

Results of physiological and biochemical characterization using methods that were described previously (Kämpfer et al., 1991) are given in the species description. Strain CCUG $53761 \mathrm{~A}^{\mathrm{T}}$ was able to utilize some organic acids but no sugars or sugar-related compounds. On the basis of the phylogenetic and chemotaxonomic data, strain CCUG

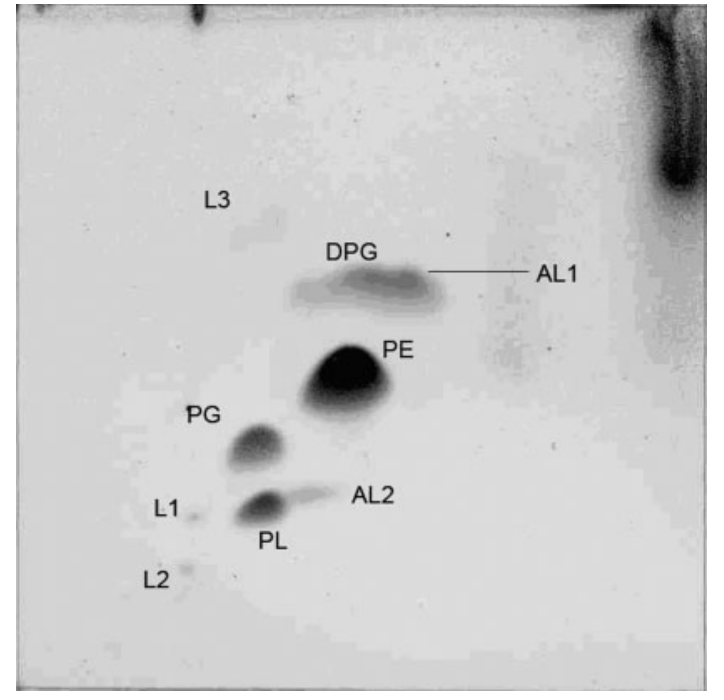

Fig. 2. Total polar lipid profile of strain CCUG $53761 A^{\top}$ after twodimensional TLC and detection with molybdatophosphoric acid. PE, Phosphatidylethanolamine; DPG, diphosphatidylglycerol; PG, phosphatidylglycerol; AL1-2, unknown aminolipids; PL, unknown phospholipid; L1-3, unknown polar lipids.

$53761 \mathrm{~A}^{\mathrm{T}}$ is different from all other genera belonging to the family Alcaligenaceae (Tables 1 and 2). For this reason, a new genus and species are proposed, with the name Paenalcaligenes hominis gen. nov., sp. nov.

\section{Description of Paenalcaligenes gen. nov.}

Paenalcaligenes (Pa.en.al.ca.li'ge.nes. L. adv. paene nearly, almost; N.L. masc. n. Alcaligenes a bacterial genus name; N.L. masc. n. Paenalcaligenes almost Alcaligenes).

Cells are Gram-stain-negative, motile, short rods, 1.3$2.0 \mu \mathrm{m}$ long and $0.2-0.8 \mu \mathrm{m}$ wide. Oxidase-positive, showing an aerobic respiratory metabolism. Good growth occurs after $24 \mathrm{~h}$ incubation on nutrient agar at $25-30{ }^{\circ} \mathrm{C}$. The polyamine pattern is composed of the major compound putrescine and moderate amounts of spermidine. Minor amounts of spermine and cadaverine may be present, but 2-hydroxyputrescine is not detectable. The quinone system is ubiquinone Q-8 with minor amounts of Q-7. The polar lipid contains diphosphatidylglycerol, phosphatidylglycerol, phosphatidylethanolamine and the specific unidentified phospholipid PL (Fig. 2). The major fatty acids are $\mathrm{C}_{16: 0}$, $\mathrm{C}_{17: 0}$ cyclo and summed feature $3\left(\mathrm{C}_{16: 1} \omega 7 c\right.$ and/or $\mathrm{C}_{15: 0}$ iso 2-OH); $\mathrm{C}_{12: 0} 2-\mathrm{OH}$ is not detected. The type species is Paenalcaligenes hominis. The DNA G $+\mathrm{C}$ content of the type strain of the type species is $57 \mathrm{~mol} \%$.

\section{Description of Paenalcaligenes hominis sp. nov.}

Paenalcaligenes hominis (ho'mi.nis. L. gen. n. hominis of a man, of a human being, named because the type and only known strain is of human origin). 
Table 1. Relative fatty acid compositions of the genera Paenalcaligenes gen. nov., Alcaligenes, Castellaniella, Pusillimonas, Achromobacter, Pigmentiphaga and Kerstersia

Genera: 1, Paenalcaligenes gen. nov.; 2, Alcaligenes (data from Coenye et al., 2003b); 3, Castellaniella (data from this study for C. defragrans DSM $12141^{\mathrm{T}}$ and C. denitrificans TJ4); 4, Pusillimonas (unless indicated, data from Stolz et al., 2005); 5, Achromobacter (Coenye et al., 2003a); 6, Pigmentiphaga (Blümel et al., 2001); 7, Kerstersia (Coenye et al., 2003b). Values are percentages of total fatty acids. tr, Trace amounts present; -, not detected/not reported. The presence or absence of the fatty acids in bold is of particular importance for differentiation among the listed genera; relative amounts of all listed fatty acids are also helpful for differentiation. Data for strain CCUG $53761 \mathrm{~A}^{\mathrm{T}}$ and strains of Castellaniella species were obtained in this study using cells grown on TSA (Oxoid) at $30{ }^{\circ} \mathrm{C}$ for $24 \mathrm{~h}$ prior to analysis. C. defragrans DSM $12141^{\mathrm{T}}$ also contained small amounts of $\mathrm{C}_{12: 0}$ aldehyde $(2.8 \%), \mathrm{C}_{15: 0}(0.4 \%), \mathrm{C}_{17: 0}(0.3 \%)$ and iso- $\mathrm{C}_{19: 0}(0.3 \%)$. C. denitrificans $\mathrm{TJ} 4$ also contained small amounts of an unknown fatty acid $(1.8 \%), \mathrm{C}_{15: 0}(1.4 \%), \mathrm{C}_{17: 0}(0.6 \%)$ and iso- $\mathrm{C}_{19: 0}(0.7 \%)$.

\begin{tabular}{|c|c|c|c|c|c|c|c|}
\hline Fatty acid & 1 & 2 & 3 & 4 & 5 & 6 & 7 \\
\hline $\mathrm{C}_{10: 0}$ & - & $0-2.5$ & $0-0.4$ & $\operatorname{tr}$ & - & - & - \\
\hline $\mathrm{C}_{10: 0} 3-\mathrm{OH}$ & - & - & - & - & - & 2.9 & - \\
\hline $\mathrm{C}_{12: 0}$ & 3.0 & $\operatorname{tr}-3.2$ & $5.7-7.8$ & 4.0 & $\operatorname{tr}$ & - & - \\
\hline Summed feature $2^{\star}$ & 3.6 & - & $\operatorname{tr}-0.1$ & - & - & - & - \\
\hline $\mathrm{C}_{12: 0} 2-\mathrm{OH}$ & - & $1.9-3.0$ & - & 3.0 & $2.5-3.5$ & - & $\operatorname{tr}$ \\
\hline $\mathrm{C}_{14: 0}$ & 2.2 & $\operatorname{tr}-2.2$ & $0.5-1.0$ & - & $1.1-5.6$ & - & 5.7 \\
\hline $\mathrm{C}_{14: 0} 2-\mathrm{OH}$ & - & - & - & - & $0-4.0$ & 4.0 & 4.3 \\
\hline $\mathrm{C}_{14: 0} 3-\mathrm{OH}$ & 2.3 & $0-8.6$ & $6.6-8.9$ & 8.0 & $8.6-12.5$ & 4.6 & 12.1 \\
\hline Summed feature $3^{*}$ & 24.0 & $10.3-30.4$ & $11.7-36.0$ & $\operatorname{tr}$ & $5.3-18.1$ & - & 3.9 \\
\hline $\mathrm{C}_{16: 0}$ & 32.0 & $30.6-35.8$ & $27.9-29.6$ & 19.0 & $28.2-39.7$ & 39.9 & 33.8 \\
\hline $\mathrm{C}_{17: 0}$ cyclo & 16.8 & $9.5-27.7$ & $2.3-22.3$ & 31.0 & $17.3-31.8$ & 21.9 & 23.6 \\
\hline $\mathrm{C}_{16: 0} 2-\mathrm{OH}$ & - & - & - & $\operatorname{tr}$ & $\operatorname{tr}-2.4$ & 4.8 & - \\
\hline $\mathrm{C}_{16: 0} 3-\mathrm{OH}$ & - & - & $0-0.4$ & - & - & - & - \\
\hline $\mathrm{C}_{18: 1} \omega 7 c$ & 9.1 & $1.1-11.2$ & $11.0-19.8$ & $\operatorname{tr}$ & $1.8-5.2$ & 9.8 & 10.7 \\
\hline$C_{18: 0}$ & 2.6 & $\operatorname{tr}-1.1$ & $0-0.5$ & 3.0 & $1.8-2.1$ & - & 2.6 \\
\hline $\mathrm{C}_{19: 0}$ cyclo $\omega 8 \mathrm{c}$ & 0.7 & $\operatorname{tr}$ & $0-2.3$ & 27.0 & $\operatorname{tr}$ & 12.2 & 2.0 \\
\hline
\end{tabular}

${ }^{\star}$ Summed features are groups of two or three fatty acids that cannot be separated using the MIDI System. Summed feature 2 contained $\mathrm{C}_{12: 0}$ aldehyde and/or an unknown fatty acid; summed feature 3 contained $\mathrm{C}_{16: 1} \omega 7 \mathrm{c}$ and/or iso- $\mathrm{C}_{15: 0} 2-\mathrm{OH}$.

The description is the same as for the genus, with the following additions. On NA, colonies are beige and circular with an entire margin. Grows at 30,37 and $42{ }^{\circ} \mathrm{C}$; no

Table 2. Chemotaxonomic characteristics that distinguish strain CCUG $53761 \mathrm{~A}^{\top}$ from the type strains of the type species of Alcaligenes, Castellaniella and Pusillimonas

Strains: 1 , CCUG $53761 \mathrm{~A}^{\mathrm{T}}$; 2, Alcaligenes faecalis DSM $30030^{\mathrm{T}}$ (data from Stolz et al., 2005); 3, Castellaniella defragrans $\mathrm{NKNTAU}^{\mathrm{T}}$ (Kämpfer et al., 2006); 4, Pusillimonas noertemannii $\mathrm{BN}^{\mathrm{T}}$ (Stolz et al., 2005). Lipids are designated according to Fig. 2 and these may vary from the designations used by Stolz et al. (2005) and Kämpfer et al. (2006).

\begin{tabular}{|lcccc|}
\hline Characteristic & $\mathbf{1}$ & $\mathbf{2}$ & $\mathbf{3}$ & $\mathbf{4}$ \\
\hline Polyamine profile & & & & \\
2-Hydroxyputrescine & - & + & + & + \\
Polar lipid profile & & & & \\
PL & + & - & - & - \\
AL2 & + & + & + & - \\
AL1 & - & + & + & + \\
\hline
\end{tabular}

growth at $4{ }^{\circ} \mathrm{C}$. L-Alanine $p$-nitroanilide (pNA) is hydrolysed, on the basis of the method described by Kämpfer et al. (1991). The following compounds are not hydrolysed: p-nitrophenyl (pNP) $\beta$-D-galactopyranoside, pNP $\beta$-Dglucuronide, $\mathrm{pNP} \alpha$-D-glucopyranoside, $\mathrm{pNP} \beta$-D-glucopyranoside, $\mathrm{pNP} \beta$-D-xylopyranoside, bis-pNP phosphate, bis-pNP phenylphosphonate, bis-pNP phosphorylcholine, L-aniline pNA, $\gamma$-L-glutamate $\mathrm{pNA}$ and L-proline pNA. The following compounds are used as sole sources of carbon on the basis of the method described by Kämpfer et al. (1991): acetate, cis- and trans-aconitate, pyruvate, fumarate, DL-3hydroxybutyrate and DL-lactate. The following compounds are not assimilated: $N$-acetylgalactosamine, $N$-acetylglucosamine, L-arabinose, L-arbutin, cellobiose, D-fructose, Dgalactose, $\mathrm{D}$-glucose, $\mathrm{D}$-gluconate, maltose, $\mathrm{D}$-mannose, $\alpha$ melibiose, L-rhamnose, D-ribose, sucrose, salicin, trehalose, D-xylose, adonitol, myo-inositol, maltitol, D-mannitol, Dsorbitol, putrescine, adipate, azelate, 4-aminobutyrate, citrate, glutarate, itaconate, L-malate, mesaconate, 2oxoglutarate, propionate, suberate, L-alanine, $\beta$-alanine, L-aspartate, L-leucine, L-ornithine, L-proline, L-histidine, Lphenylalanine, L-serine, L-tryptophan, 3-hydroxybenzoate and phenylacetate. No acids are produced from glucose, lactose, sucrose, D-mannitol, dulcitol, salicin, adonitol, 
inositol, sorbitol, L-arabinose, raffinose, rhamnose, maltose, D-xylose, trehalose, cellobiose, methyl D-glucoside, erythritol, melibiose, D-arabitol or D-mannose. Exhibits the chemotaxonomic characteristics listed in the genus description. In addition, two unidentified aminolipids (AL1, AL2) and three unidentified lipids (L1, L2, L3) are detectable.

The type strain is CCUG $53761 \mathrm{~A}^{\mathrm{T}}\left(=\mathrm{CCM} 7698^{\mathrm{T}}\right)$, isolated from human blood from an 85-year-old man in Göteborg, Sweden.

\section{Acknowledgements}

We thank Dr Jean Euzéby for his advice on the name of the genus and Gundula Will and Maria Sowinsky for excellent technical assistance.

\section{References}

Altenburger, P., Busse, H.-J., Kämpfer, P., Lubitz, W. \& Makristathis, A. (1996). Classification of bacteria isolated from a medieval wall painting. J Biotechnol 47, 39-52.

Auling, G., Busse, H.-J., Pilz, F., Webb, L., Kneifel, H. \& Claus, D. (1991). Rapid differentiation, by polyamine analysis, of Xanthomonas strains from phytopathogenic pseudomonads and other members of the class Proteobacteria interacting with plants. Int J Syst Bacteriol 41 223-228.

Blümel, S., Mark, B., Busse, H.-J., Kämpfer, P. \& Stolz, A. (2001) Pigmentiphaga kullae gen. nov., sp. nov., a novel member of the family Alcaligenaceae with the ability to decolorize azo dyes aerobically. Int $J$ Syst Evol Microbiol 51, 1867-1871.

Busse, J. \& Auling, G. (1988). Polyamine pattern as a chemotaxonomic marker within the Proteobacteria. Syst Appl Microbiol 11, 1-8.

Busse, H.-J., El-Banna, T., Oyaizu, H. \& Auling, G. (1992). Identification of xenobiotic-degrading isolates from the beta subclass of the Proteobacteria by a polyphasic approach including 16S rRNA partial sequencing. Int J Syst Bacteriol 42, 19-26.

Coenye, T., Vancanneyt, M., Falsen, E., Swings, J. \& Vandamme, P. (2003a). Achromobacter insolitus sp. nov. and Achromobacter spanius sp. nov., two novel species isolated from human clinical samples. Int $J$ Syst Evol Microbiol 53, 1819-1824.

Coenye, T., Vancanneyt, M., Cnockaert, M. C., Falsen, E., Swings, J. \& Vandamme, P. (2003b). Kerstersia gyiorum gen. nov., sp. nov., a novel Alcaligenes faecalis-like organism isolated from human clinical samples, and reclassification of Alcaligenes hominis Rüger and Tan 1983 as Achromobacter hominis comb. nov. Int J Syst Evol Microbiol 53, 1825-1831.

Coenye, T., Vanlaere, E., Samyn, E., Falsen, E., Larsson, P. \& Vandamme, P. (2005). Advenella incenata gen. nov., sp. nov., a novel member of the Alcaligenaceae, isolated from various clinical samples. Int J Syst Evol Microbiol 55, 251-256.

De Ley, J., Segers, P., Kersters, K., Mannheim, W. \& Lievens, A. (1986). Intra- and intergeneric similarities of the Bordetella ribosomal ribonucleic acid cistrons: proposal for a new family, Alcaligenaceae. Int J Syst Bacteriol 36, 405-414.

Gerhardt, P., Murray, R. G. E., Wood, W. A. \& Krieg, N. R. (editors) (1994). Methods for General and Molecular Bacteriology. Washington, DC: American Society for Microbiology.

Ghosh, W., Badchi, A., Manda, S., Dam, B. \& Roy, P. (2005). Tetrathiobacter kashmirensis gen. nov., sp. nov., a novel mesophilic, neutrophilic, tetrathionate-oxidizing, facultatively chemolithotrophic betaproteobacterium isolated from soil from a temperate orchard in Jammu and Kashmir, India. Int J Syst Evol Microbiol 55, 17791787.

Hamana, K. \& Takeuchi, M. (1998). Polyamine profiles as chemotaxonomic markers within alpha, beta, gamma, delta, and epsilon subclasses of class Proteobacteria: distribution of 2-hydroxyputrescine and homospermidine. Microbiol Cult Collect 14, 1-14.

Hamana, K., Saito, T. \& Okada, M. (2000). Polyamine profiles within the beta subclass of the class Proteobacteria: distribution of 2hydroxyputrescine. Microbiol Cult Collect 16, 63-69.

Hamana, K., Sato, W., Gouma, K., Yu, J., Ino, Y., Umemura, Y., Mochizuki, C., Takatsuka, K., Kigure, Y. \& other authors (2007). Cellular polyamine catalogues of the five classes of the phylum Proteobacteria: distributions of homospermidine within the class Alphaproteobacteria, hydroxyputrescine within the class Betaproteobacteria, norspermidine within the class Gammaproteobacteria, and spermidine within the classes Deltaproteobacteria and Epsilonproteobacteria. Ann Gunma Health Sci 27, $1-16$.

Kämpfer, P. \& Kroppenstedt, R. M. (1996). Numerical analysis of fatty acid patterns of coryneform bacteria and related taxa. Can J Microbiol 42, 989-1005.

Kämpfer, P., Steiof, M. \& Dott, W. (1991). Microbiological characterization of a fuel-oil contaminated site including numerical identification of heterotrophic water and soil bacteria. Microb Ecol 21, 227-251.

Kämpfer, P., Dreyer, U., Neef, A., Dott, W. \& Busse, H.-J. (2003). Chryseobacterium defluvii sp. nov., isolated from wastewater. Int J Syst Evol Microbiol 53, 93-97.

Kämpfer, P., Denger, K., Cook, A. M., Lee, S.-T., Jäckel, U., Denner, E. B. M. \& Busse, H.-J. (2006). Castellaniella gen. nov., to accommodate the phylogenetic lineage of Alcaligenes defragrans, and proposal of Castellaniella defragrans gen. nov., comb. nov. and Castellaniella denitrificans sp. nov. Int J Syst Evol Microbiol 56, 815-819.

Kirchhof, G., Eckert, B., Stoffels, M., Baldani, J. I., Reis, V. M. \& Hartmann, A. (2001). Herbaspirillum frisingense sp. nov., a new nitrogen-fixing bacterial species that occurs in C4-fibre plants. Int $J$ Syst Evol Microbiol 51, 157-168.

Lane, D. J. (1991). 16S/23S rRNA sequencing In Nucleic Acid Techniques in Bacterial Systematics, pp. 115-175. Edited by E. Stackebrandt \& M. Goodfellow. Chichester: Wiley.

Ludwig, W., Strunk, O., Westram, R., Richter, L., Meier, H., Yadhukumar, Buchner, A., Lai, T., Steppi, S. \& other authors (2004). ARB: a software environment for sequence data. Nucleic Acids Res 32, 1363-1371.

Moreira, C., Rainey, F. A., Nobre, M. F., da Silva, M. T. \& da Costa, M. S. (2000). Tepidimonas ignava gen. nov., sp. nov., a new chemolithoheterotrophic and slightly thermophilic member of the $\beta$-Proteobacteria. Int J Syst Evol Microbiol 50, 735-742.

Olsen, G. J., Matsuda, H., Hagström, R. \& Overbeek, R. (1994). fastDNAml: a tool for construction of phylogenetic trees of DNA sequences using maximum likelihood. Comput Appl Biosci 10, 41-48.

Pruesse, E., Quast, C., Knittel, K., Fuchs, B. M., Ludwig, W., Peplies, J. \& Glöckner, F. O. (2007). SILVA: a comprehensive online resource for quality checked and aligned ribosomal RNA sequence data compatible with ARB. Nucleic Acids Res 35, 7188-7196.

Rossau, R., Kersters, K., Falsen, E., Jantzen, E., Segers, P., Union, A., Nehls, L. \& De Ley, J. (1987). Oligella, a new genus including Oligella urethralis comb. nov. (formerly Moraxella urethralis), and Oligella ureolytica sp. nov. (formerly CDC group IVe): relationship to Taylorella equigenitalis and related taxa. Int J Syst Bacteriol 37, 198210. 
Stolz, A., Bürger, S., Kuhm, A., Kämpfer, P. \& Busse, H.-J. (2005). Pusillimonas noertemannii gen. nov., sp. nov., a new member of the family Alcaligenaceae that degrades substituted salicylates. Int J Syst Evol Microbiol 55, 1077-1081.

Stolz, A., Busse, H.-J. \& Kämpfer, P. (2007). Pseudomonas knackmussii sp. nov. Int J Syst Evol Microbiol 57, 572-576.

Tamura, K., Dudley, J., Nei, M. \& Kumar, S. (2007). MEGA4: molecular evolutionary genetics analysis (MEGA) software version 4.0. Mol Biol Evol 24, 1596-1599.

Tindall, B. J. (1990a). Lipid composition of Halobacterium lacusprofundi. FEMS Microbiol Lett 66, 199-202.

Tindall, B. J. (1990b). A comparative study of the lipid composition of Halobacterium saccharovorum from various sources. Syst Appl Microbiol 13, 128-130.

Vandamme, P., Segers, P., Ryll, M., Hommez, J., Vancanneyt, M., Coopman, R., De Baere, R., Van de Peer, Y., Kersters, K. \& other authors (1998). Pelistega europaea gen. nov., sp. nov., a bacterium associated with respiratory disease in pigeons: taxonomic structure and phylogenetic allocation. Int J Syst Bacteriol 48, 431-440.

Willems, A., Gilhaus, H., Beer, W., Mietke, H., Gelderblom, H. R., Burghardt, B., Voigt, W. \& Reissbrodt, R. (2002). Brackiella oedipodis gen. nov., sp. nov., Gram-negative, oxidase-positive rods that cause endocarditis of cotton-topped tamarin (Saguinus oedipus). Int J Syst Evol Microbiol 52, 179-186.

Yabuuchi, E., Kawamura, Y., Kosako, Y. \& Ezaki, T. (1998). Emendation of the genus Achromobacter and Achromobacter xylosoxidans (Yabuuchi and Yano) and proposal of Achromobacter ruhlandii (Packer and Vishniac) comb. nov., Achromobacter piechaudii (Kirefjian et al.) comb nov., and Achromobacter xylosoxidans subsp. denitrificans (Rüger and Tan) comb. nov. Microbiol Immunol 42, 429438.

Yokota, A., Akagawa-Matsushita, M., Hiraishi, A., Katayama, Y., Urakami, T. \& Yamasato, K. (1992). Distribution of quinone systems in microorganisms: Gram-negative eubacteria. Bull Jpn Fed Cult Coll 8, 136-171. 